Valóságos könyvtár - könyvtári valóság. Könyvtár- és információtudományi tanulmányok 2018. Szerk. Kiszl Péter, Csík Tibor.

Budapest, ELTE BTK Könyvtár- és Információtudományi Intézet. 2018. 345-350.

\title{
COURAGE: AZ ELLENZÉKI KULTÚRA ADATBÁZISA
}

\section{APOR PÉTER - BÓDI LÓRÁNT - HORVÁTH SÁNDOR - MICSIK ANDRÁS - SCHEIBNER TAMÁS}

\section{TARTALMI ÖSSZEFOGLALÓ}

Az államszocialista rendszerek erodálódását, majd a rendszerváltással jelentkező bukásukat nem kizárólag nagyhatalmi játszmák eredményezték, hanem a - legkülönfélébb mozgalmakat és műfajokat felölelő - „földalatti” civil szerveződések és a kulturális szféra ellenállása is. Az MTA Bölcsészettudományi Kutatóközpont koordinálásában több mint húsz országban, tizenkét partnerintézmény bevonásával zajló nemzetközi kutatóprogram kísérletet tesz eme örökség történeti feldolgozására és láthatóvá tételére. A COURAGE kutatóprogramot a Horizont 2020, az Európai Unió Kutatási és Innovációs Keretprogramja támogatja. A kutatóprogram a kulturális ellenállás gyüjteményeinek közös adatbázisát hozza létre, lefedve az egykori szocialista blokk tagállamait. A felépülő adatbázis egyfajta metaarchívumként funkcionál, és nagy segítség lehet a történelem, irodalom vagy múvészeti oktatás területén, hiszen képes egyszerre multimediális tartalmakat megjeleníteni, illetve a szabad, kreatív bejárást biztosítani a felhasználóknak.

\section{Bevezetés}

Tematikus szempontból az ellenkultúra heterogén fogalma alá tartoznak a film, az előadó-mûvészet, a zene, a tánc, a képzőművészet, az ifjúsági szubkultúrák, a nemzeti hagyományőrző mozgalmak (például a táncház mozgalom), az emberi jogi és környezetvédő, a rejtve működő vallási közösségek vagy az emigráns csoportok gyűjteményei. Utóbbiak esetében különösen fontos, hogy az emigrációs közösségek miként járultak hozzá e gyűjtemények létrejöttéhez, fenntartásához és népszerűsítéséhez.

A kutatás középpontjában nem önmagában az ellenkultúra vagy kulturális ellenállás mozgalmi aspektusai állnak, hanem kettős módon az ellenkulturális relikviákat gyüjtő magán- és közgyűjtemények története (archívumok, levéltárak, múzeumok, privátgyűjtemények) és elemzése - tágabb szociális, politikai és kulturális összefüggéseikben -, illetve maga a kulturális megőrzés társadalmi gyakorlata (különösen a tiltott vagy megtűrt gyűjtőtevékenység), mint ellenkulturális praxis. Az állami intézmények több módon hoztak létre ellenkultúrára vonatkozó gyűjteményeket: valahol az állományt hivatalosan, de az olvasóközönség nagy részétől elzárva gyarapították, máshol félhivatalos, megtűrt gyakorlatként történt a gyűjteményezés, megint másutt 1989 után hozták létre az ellenzékiséget dokumentáló gyüjteményeket. A kutatás éppen ezért annak megértésére is törekszik, miként változott az ellenzékiség kultúráját regisztráló gyüjteményépítési gyakorlat 
a rendszerváltás előtt és után. A gyűjtemények dokumentumai, tárgyai és audiovizuális tartalmai által megjelenített anyagi kultúra hogyan alakult át? Mi számított gyújtésre érdemesnek és mi nem? Mely tárgyakból vált „,történeti forrás”, melyekből nem, és mi volt ennek a szelekciónak az oka? Összegezve, a gyűjtemények rendszerezését és annak elvi alapjait, különös tekintettel az ún. adathalmaz és referencia rendszerekre: hogyan és mi alapján gyűjtötték az anyagot? Szintén a kutatás részét képezik a gyüjtemények létrehozásában, gondozásában résztvevő személyek élettörténete és társadalmi háttere is, ahogy a gyűjteményeket kezelő intézmények szociológiai, jogi, tulajdonosi és anyagi aspektusai is.

A humántudományok diszciplináris kihívásai közül kiemelkedő kérdés a korszerű informatikai rendszerekkel való együttmúködés. A projekt ezen kihívásoknak megfelelően a kanonikus tudásmegosztási formákon túl (szakkönyv, tankönyv) más csatornákon (pl. a közösségi médián keresztül) is kísérletet tesz a létrejövő eredmények közvetítésére. A Magyar Tudományos Akadémia Számítástechnikai és Automatizálási Kutatóintézet (MTA SZTAKI) által kialakított informatikai rendszer (az ún. online registry) segít olyan struktúrákba rendezni a gyújteményekkel kapcsolatos információkat, melyek lehetôvé teszik egy akkumulatív, ugyanakkor hálózatosan szerveződő tudástár létrejöttét, melyet a kutatásban részt vevő országok kutatói könnyedén gyarapíthatnak. Ezen struktúra különösen alkalmas komplex - egymással érintkező, transznacionális - történeti jelenségek bemutatására. A rendszer azt is biztosítja - szerkesztői kontroll mellett -, hogy a tudástár önkéntes alapon (lehetôség van arra, hogy gyűjtemények tulajdonosai, kezelői, kutatói szabadon felvigyék az adott kollekciót az adatbázisba) bővülhessen.

A kutatóprogram tehát a kulturális ellenállás gyűjteményeinek közös adatbázisát hozza létre, lefedve ezzel az egykori szocialista blokk tagállamait (1. ábra). Így tehát a felépülő adatbázis - funkcióját tekintve - egyfajta metaarchívumként is funkcionál (mindamellett, hogy gyújteményezési munkát a projekt nem végez), mely megfelelő közegét az online térben nyerte el. A gyüjteményeket standardizált és összehasonlítható formában írjuk le, így könnyen kereshetők és különböző szempontok szerint listázhatók is. A kutatóprogram segít megérteni, miként múködnek a gyüjtemények, milyen funkciót töltenek be az adott társadalomban, hogyan jelenítik meg anyagaikat és kutatási eredményeiket a hazai és a nemzetközi közönség előtt. Kiemelt cél, hogy a kulturális ellenállás történeti gyökereinek és örökségének megértése segítségével lehetôvé váljon a gyűjtemények társadalmi hatásának és hatókörének növelése is. 


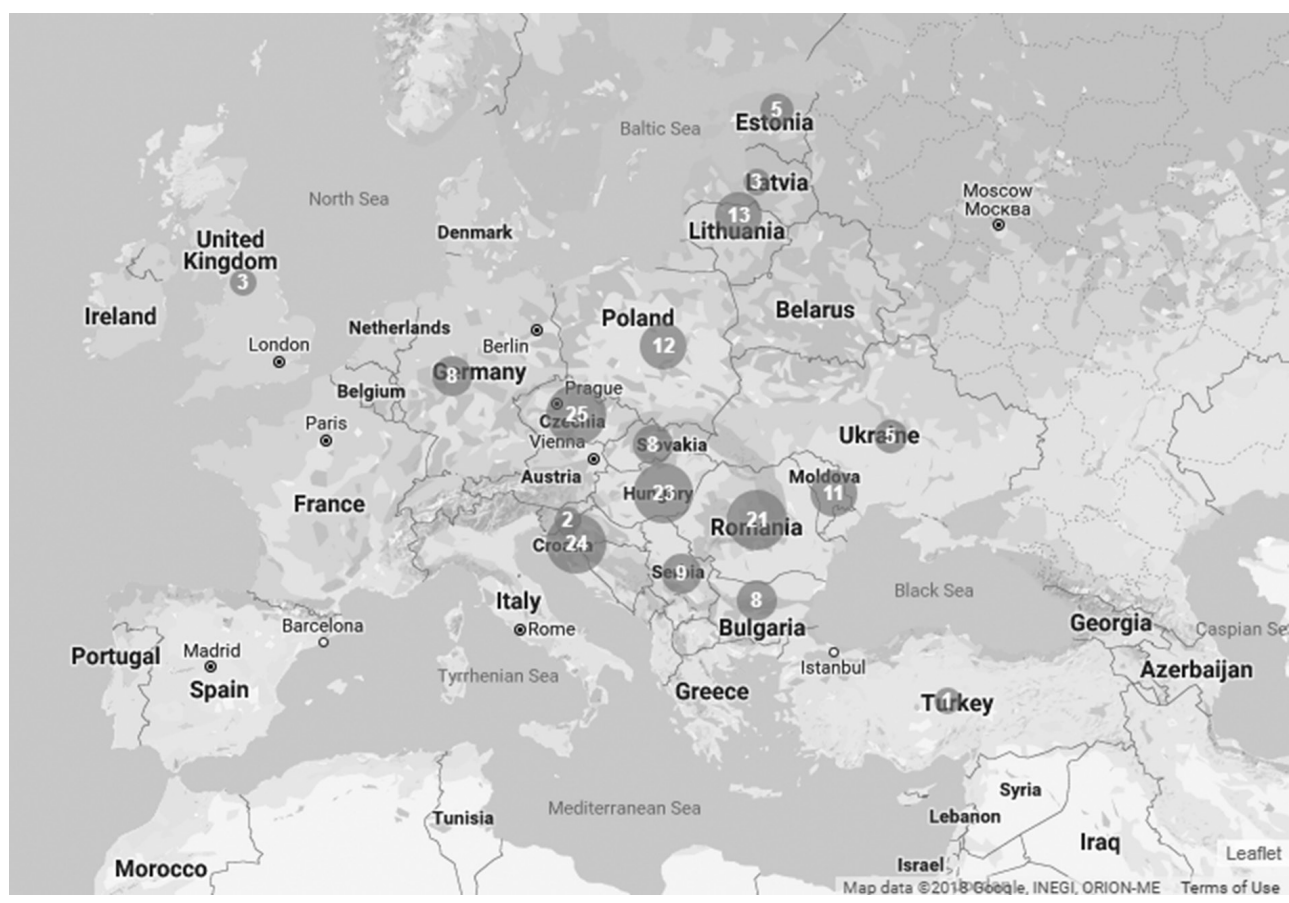

1. ábra: A feltárt gyüjtemények országok szerinti megoszlása 2018 elején

Az MTA SZTAKI által a projekt számára felállított szoftver infrastruktúra három fő eleme: egy Redmine feladatkezelő, egy WordPress portálmotor és a Vitro szemantikus web platform, amely a projekt tudástárát valósítja meg. A feladatkezelő és a tudástár összekötésével az egyes gyűjteményekkel kapcsolatos problémák és tennivalók válnak követhetővé és menedzselhetővé. A WordPress szolgáltatja a projekt angol nyelvű és nemzeti portáljait, melyen keresztül a tudástár nyilvános részét böngészheti a közönség. A tudástár különféle nyelvi nézetei nemcsak a megjelenő szövegezésben különböznek, hanem abban is, hogy az adott nyelvvel, országgal kapcsolatos gyújteményleírások kiemelve jelennek meg (2. ábra). A tudástár lehetőséget nyújt arra, hogy a szöveges leírásokat párhuzamosan a résztvevő országok összes nyelvére lefordíthassuk, de általában ez csak két nyelvre, az angolra és a gyüjtemény fő nyelvére elvárt.

A projekt angol nyelvű honlapja a cultural-opposition.eu webcímen található, míg a nemzeti honlapváltozatok az országkóddal jelölt címeken, pl. hu.cultural-opposition.eu címen. A tudástár a „gyűjtemények” feliratra kattintva érhető el. Itt gyűjtemények, szervezetek, személyek, események és ajánlott tételek egységes leírásai böngészhetők. Ezen kívül szöveges keresést, illetve szűrést is el tudunk végezni a feltárt tételeken. A szűrési feltételek a tétel típusa szerint változók, gyűjtemények esetében téma, a tartalom típusa, ország, gyűjtőterület, nyelv, az alapítás ideje, valamint online hozzáférhetőség szerint le- 
het kiválasztani a megjelenítendő elemeket. Az egyes elemekhez képgaléria és térképes megjelenítő is tartozik, és könnyen tovább lehet navigálni a kapcsolódó más tételekhez (például egy gyűjtemény alapítóinak, gyüjtőinek vagy támogatóinak leírásaihoz).
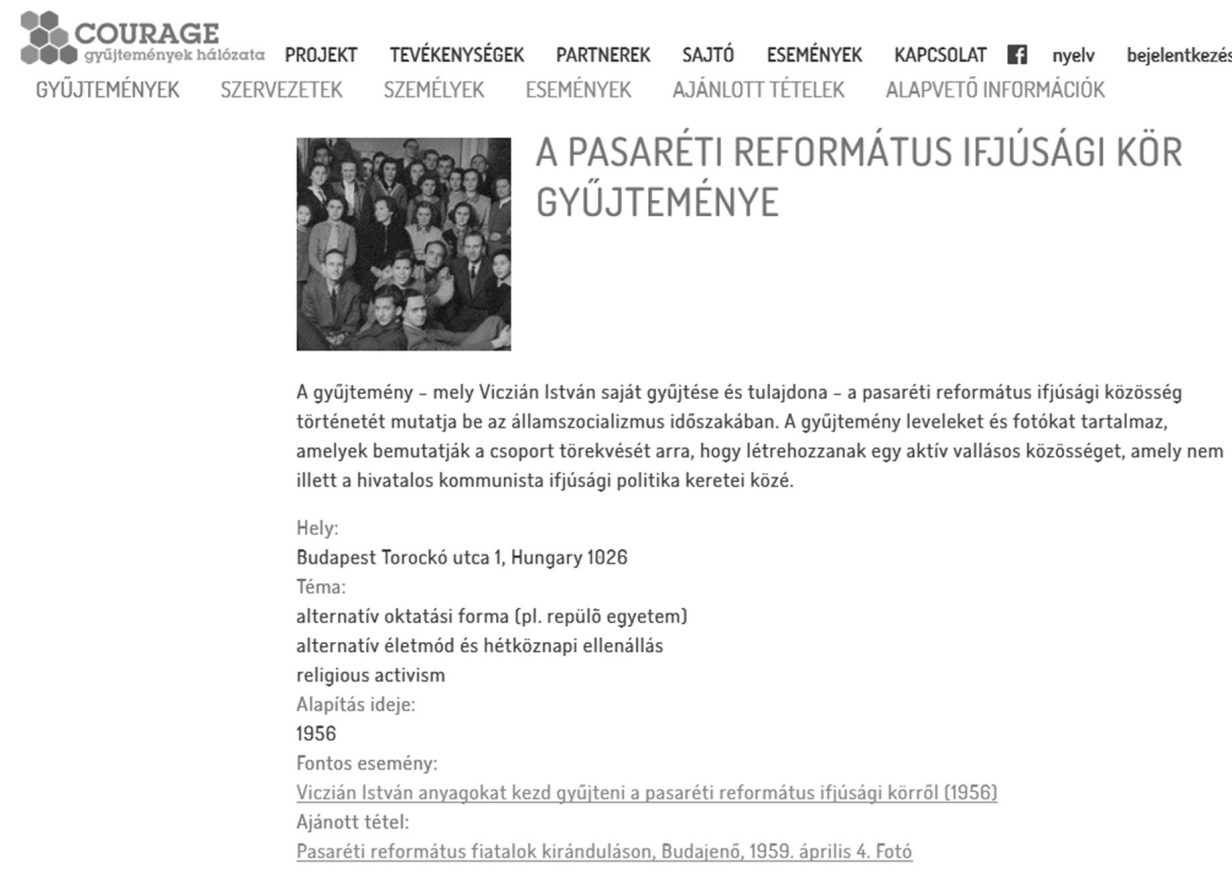
történetét mutatja be az államszocializmus időszakában. A gyüjtemény leveleket és fotókat tartalmaz, amelyek bemutatják a csoport törekvését arra, hogy létrehozzanak egy aktiv vallásos közösséget, amely nem illett a hivatalos kommunista ifjúsági politika keretei közé.

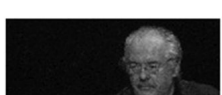

\section{KISFALUDY ANDRÁS MAGÁNGYÜJTEMÉNYE}

2. ábra: Részlet a nyilvános regiszter magyar nyelvú nézetéböl

A fordítások és általában a leírások minőségének biztosítására hét lépésből álló ellenőrzési folyamatot építettünk a tudástárba, mely a nemzeti felelősökön, anyanyelvi lektorokon és központi ellenőrzési rendszeren keresztül engedélyezi egy anyag publikálását. A Linked Data technológia alkalmazása sokféle adatexportálási és adatbányászati lehetőséget nyit meg számunkra; a tudástár részleteit tudományos adatként regisztráljuk a DataCite rendszerben, miáltal DOI-val hivatkozhatóvá válnak. Továbbá tervezünk adatszolgáltatást az Europeana, Academia.edu és más rendszerek felé is. A tudástárban 2018 februárjában összesen megtalálható (nyilvános és feldolgozás alatt lévő) leírások száma jelenleg körülbelül a következő: 400 gyűjtemény, 1300 személy, 600 szervezet, 600 esemény, 400 interjú és 800 ajánlott gyújteményi tétel. Ezek a 2018 februári helyzetet rögzítő számok is mutatják, hogy olyan hálós adatmodellel dolgozunk, melyben sokféle entitás leírása szerepel, külön hangsúllyal az entitások közötti kapcsolatokra és azok földrajzi elhelyezkedésére. 
A gyűjtemények tárgyainak, dokumentumainak, audiovizuális tartalmának felkutatása és regisztrálása önmagában még nem elegendő. A COURAGE azt is szeretné elérni, hogy az ellenkultúra témája a térségünk után a nyugati történelemoktatásban is hangsúlyosabban jelenjék meg. Az adatbázis nagy segítség lehet a történelem-, irodalom- vagy múvészeti oktatás területén, hiszen képes egyszerre multimediális tartalmakat megjeleníteni, illetve szabad, kreatív bejárást biztosítani a felhasználóknak. A projekt további célja egy, a formális és informális pedagógiai módszereknek egyaránt megfelelő digitális tananyag fejlesztése különböző korosztályok és célcsoportok számára. A tananyag kidolgozása az egyes területek szakértőinek (múzeumpedagógusok, történelemtanárok stb.) bevonásával történik, és az eredmény elérhető lesz a projekt nemzeti és központi portálán egyaránt. Ez egyúttal kísérlet is arra nézve, hogy a jelenkori történelem mennyivel érdekesebben, színesebben adható elő online formában akár közösségépítő tartalomként, mint egyetlen tankönyvben. A tervek között szerepel egy virtuális és egy vándorkiállítás, melyeknek kifejezetten az internethasználó fiatal generáció a célközönsége. A kiállítás a kulturális ellenállás olyan fontos értékeit szeretné hangsúlyozni, mint a demokratikus részvétel, a civil kurázsi, a szolidaritás és a kultúrák diverzitása országonként más-más motívumokon keresztül. A kiállításokkal a kelet-európai ellenállás szokatlan, eddig kevéssé ismert oldalait szeretnénk a közönséggel megismertetni, így a lengyelországi Szolidaritás-mozgalom, a magyarországi demokratikus ellenzék vagy a szamizdat sajtó mellett hangsúlyt fektetünk az ellenállás nemzetközi kapcsolataira, a kulturális szcénára és az életmód-szubkultúrák bemutatására is.

A kutatóprogram vállalt feladatai közé tartozik szakpolitikai ajánlások előállítása. E tanulmányok segítséget nyújtanak a politikusok és a támogatást kiíró intézmények számára felmérni a kulturális ellenállás gyújteményeinek társadalmi hatását és céljait, lehetőséget biztosítva további közös projektek létrehozásának megvitatására. Az emlékezetpolitikában fontos évfordulók megünneplésében is segít a gyüjtemények regisztere, amelyre támaszkodva gyorsabban megtalálhatók az ünnep szempontjából fontos anyagok. A politikai döntéshozók számára készülő országjelentések beszámolnak arról, hogyan jöttek létre a gyüjteményeket irányító intézmények, és hogyan változtak a szocializmus kései szakaszától napjainkig terjedő időszakban. Feltérképezik a kulcsszereplőket, a legalapvetôbb reményeket, az alkalmazott stratégiákat, valamint a gyújtemények politikai, jogi, pénzügyi és kulturális hátterének alapvetô változásait. A COURAGE a gyưjtemények fenntartásának legfontosabb kérdéseire irányuló ajánlásokat fogalmaz meg a politikai döntéshozók számára. Az ajánlások a kulturális ellenállás örökségének lehetséges felhasználási módjaira tesznek javaslatokat, különös tekintettel egy, az Európai Történelem Házában rendezendő kiállításra.

Végezetül a projekt további célja, hogy a kulturális mező szereplőit (a gyújtemények, szakértők és kutatók) képzési napokkal támogassa új együttmúködési hálózatok kialakításában, miközben segítséget nyújthat az adatbázis hatékony használatához is (pl. oktatás, hatékonyabb részvétel nemzetközi kulturális és tudományos pályázatok területén stb.). 
APOR PÉTER - BÓDI LÓRÁNT - HORVÁTH SÁNDOR...

\section{Irodalom}

MICSIK András - FELKER Tamás - NÁSZ Balázs: Cultural opposition in former European socialist countries: Building the COURAGE registry = ERCIM News, 111. October, 2017, 64 p. Forrás: https://ercim-news.ercim.eu/en111/special/cultural-opposition-in-formereuropean-socialist-countries-building-the-courage-registry [2018. február 27.]

Apor Péter az MTA Bölcsészettudományi Kutatóközpontjának tudományos munkatársa. Fő kutatási témái a második világháború utáni Kelet-közép Európa társadalom- és kultúrtörténete, illetve az emlékezetpolitika kérdései a térségben. Apor rendszeres résztvevője nemzetközi együttmúködésben folyó kutatásoknak és tagja az EURHISTXX, az Európai Jelenkortörténeti Hálózat felügyelőbizottságának.

Bódi Lóránt az MTA BTK Történettudományi Intézet fiatal kutatója, az MTA BTK COURAGE nemzetközi kutatóprogram munkatársa. Kutatási területe a II. világháború utáni Magyarország társadalom-, és kultúrtörténete különösen annak a mindennapokkal és a múvészettel kapcsolatos aspektusai.

Horváth Sándor az MTA Bölcsészettudományi Kutatóközpont Történettudományi Intézetében a Jelenkortörténet témacsoport vezetője és a COURAGE kutatóprogram vezető koordinátora. Alapító szerkesztője a Hungarian Historical Review-nak.

Micsik András az MTA SZTAKI Elosztott Rendszerek Osztályának tudományos főmunkatársa. A Szemantikus Web és a Linked Data technológiák alkalmazási lehetőségeit kutatja különböző környezetekben, például repozitóriumokban, számítási felhőkben és e-science megoldásokban. Több hazai tudományos repozitórium létrehozója és fejlesztője.

Scheibner Tamás az MTA BTK Történettudományi Intézet tudományos munkatársa és az ELTE BTK Magyar Irodalom és Kultúratudományi Intézetének adjunktusa. 